\title{
A New Tospovirus sp. in Cucurbit Crops in Mexico
}

\author{
M. Ciuffo, Istituto di Virologia Vegetale, Torino 10135, Italy; C. Kurowski, E. Vivoda, B. Copes, and V. Masenga, \\ Harris Moran Seed Company, Davis, CA 95618; B. W. Falk, Department of Plant Pathology, University of Califor- \\ nia, Davis 95616; and M. Turina, Istituto di Virologia Vegetale, Italy
}

\begin{abstract}
Ciuffo, M., Kurowski, C., Vivoda, E., Copes, B., Masenga, V., Falk, B. W., and Turina, M. 2009. A new Tospovirus sp. in cucurbit crops in Mexico. Plant Dis. 93:467-474.

During the 2007 growing season, melon (Cucumis melo) samples from the state of Guerrero in Mexico showing mosaic and other virus-like symptoms were collected for analysis. Electron microscopic examination of negatively stained leaf-dip extracts revealed the presence of abundant virus-like particles with features characteristic of the family Bunyaviridae. No other viral particles were observed in these preparations. However, enzyme-linked immunosorbent assays (ELISAs) specific for the most common Tospovirus spp. gave negative results. Antibodies raised against purified nucleocapsids reacted specifically with the infected leaf extracts in Western blots and double-antibody sandwich ELISA. The viral RNA was used as a template for a cDNA library, and nucleotide sequence analysis identified cloned cDNAs representing sequences corresponding to the three Tospovirus genome segments. Sequence comparisons showed that the new virus had the highest similarity to Chrysanthemum stem necrosis virus (CSNV). Phylogenetic analysis of two genome regions confirmed that this virus, provisionally named Melon severe mosaic virus (MeSMV), is a previously undescribed Tospovirus sp. belonging to the "new world" clade of Tospovirus spp. An initial survey of various cucurbit crops in various states of Mexico confirmed the widespread occurrence of this virus.
\end{abstract}

The genus Tospovirus (Bunyaviridae) $(9,18)$ includes some of the most important plant viruses causing severe diseases in agricultural, ornamental, and horticultural crops $(16,26,34)$. The type member of the genus is Tomato spotted wilt virus (TSWV; 20). Tospovirus spp. possess a tripartite single-stranded RNA genome with a negative or ambisense expression strategy (34). Genomic RNAs are encapsidated by nucleocapsid proteins $(\mathrm{N})$ and enveloped by a lipoprotein membrane (34).

The three genome segments are referred to as small (S), medium (M), and large (L). The $\mathrm{S}$ segment encodes a nonstructural protein $(\mathrm{NSs})$ in the viral sense $(2,11,31)$ and the $\mathrm{N}$ protein in the viral complementary sense (11). The $\mathrm{M}$ segment encodes in the viral sense a nonstructural protein (NSm) $(28,29)$ and, in the viral complementary sense, the precursor of the twomembrane glycoproteins $(27,38,39)$. The L segment encodes the RNA-dependent RNA polymerase protein in the viral complementary sense (11).

Cucurbit-infecting Tospovirus spp. have been identified in different countries since the 1980s, particularly in South America and Asia. Two cucurbit-infecting Tospovirus

Corresponding author: M. Turina

E-mail: m.turina@ivv.cnr.it

Accepted for publication 31 December 2008.

doi:10.1094/PDIS-93-5-0467

(C) 2009 The American Phytopathological Society spp. are included in the list of the species accepted by the International Committee on Taxonomy of Viruses (ICTV): Watermelon silver mottle virus (WSMoV), originally reported on Citrullus lanatus in Okinawa, Japan in 1982 and in 1992 in Taiwan (40); and Zucchini lethal chlorosis virus (ZLCV), reported on Cucurbita pepo in Brazil in 1999 (1). In addition, two tentative species from cucurbits have been proposed: Watermelon bud necrosis virus (WBNV), reported on cucurbits in India (13); and, more recently, Melon yellow spot virus (MYSV) on netted melon in Japan (14).

In the state of Guerrero, Mexico, several honeydew melon (Cucumis melo) plants exhibiting mosaic, leaf blistering, leaf deformation, and fruit splitting were observed. Electron-microscopic analysis of leaf-dip extracts showed only particles with the morphological features of viruses of the Tospovirus genus. Biological, serological, and molecular properties and phylogenetic analysis showed that this Tospovirus $\mathrm{sp}$. is a new and distinct species in the genus Tospovirus and is tentatively named Melon severe mosaic virus (MeSMV). Surveys showed its widespread occurrence in cucurbit crops in Mexico.

\section{MATERIALS AND METHODS}

Virus isolation and maintenance. The virus was isolated from symptomatic honeydew melon ( $C$. melo) plants during the 2007 melon-growing season in the state of Guerrero, Mexico. Symptomatic plants were first checked for TSWV presence by specific double-antibody sandwich en- zyme-linked immunosorbent assay (DASELISA) using a commercial kit from Agdia (Elkhart, IN) and our own DAS-ELISA kit (24). The virus was mechanically transferred onto C. melo and Nicotiana benthamiana plants, and leaves were stored in liquid nitrogen to be used as the source of successive mechanical inoculations. To avoid the possibility of generating deletions or mutations in the virus genome, mechanical inoculations were limited to not more than three to four serial passages. The presence of Tospovirus sp.-like virions in infected plants was confirmed by electron-microscopic observation (Philips CM10, Eindoven, the Netherlands) of crude sap negatively stained in $0.5 \%$ aqueous uranyl acetate.

Host range. Leaves of symptomatic $C$. melo and $N$. benthamiana plants showing strong mosaic symptoms 2 weeks post inoculation were homogenized with 50 $\mathrm{mM}$ phosphate buffer, $\mathrm{pH} 7$, containing 1 $\mathrm{mM}$ Na-EDTA, $5 \mathrm{mM}$ Na-DIECA, and 5 $\mathrm{mM} \mathrm{Na}$-thioglycolate (extraction buffer) and mechanically inoculated onto leaves of a series of herbaceous plants to determine the partial host range (Table 1) as previously described (35). Plants were grown in an insect-proof glasshouse at a variable temperature between 20 and $25^{\circ} \mathrm{C}$, and three individual plants for each species were inoculated when the first true leaves were fully expanded; symptoms were monitored after 1 and 4 weeks post inoculation. DAS-ELISA (as described below) was used to confirm the presence of MeSMV in both symptomatic and asymptomatic inoculated plants.

Nucleocapsid purification and antiserum production. Viral nucleocapsids were purified from $100 \mathrm{~g}$ of MeSMVinfected $N$. benthamiana plants following the method used for other Tospovirus spp. $(23,24)$. The partially purified preparation was then layered on a 10 - to $50-\%$ sucrose gradient and centrifuged at $270,000 \times g$ for $2 \mathrm{~h}$. A band corresponding to the nucleocapsids was collected, and purity was assessed by electron microscopy and by Coomassie staining of the samples separated in $10 \%$ tris-tricine sodium dodecyl sulfate polyacrylamide gel electrophoresis (SDS-PAGE) as described (35).

A polyclonal antiserum was obtained from a 'New Zealand' rabbit injected intramuscularly with the nucleocapsid suspension. Purified nucleocapsid (1 $\mathrm{mg})$ emulsified with Freund's complete adjuvant $(1: 1, \mathrm{vol} / \mathrm{vol})$ was used for the first 
injection. Booster injections were given after 2, 4, and 6 weeks with incomplete Freund's adjuvant. Blood was collected three times, every 15 days, beginning 2 weeks from the second injection. Serum was separated after overnight incubation at $4^{\circ} \mathrm{C}$ and cross-absorbed with healthy plant extract ( $N$. benthamiana). Immunoglobulin $\mathrm{G}$ (IgG) was purified through affinity chromatography on protein $G$ columns (Pharmacia, Skokie, IL) according to the manufacturer's instructions.

ELISA and Western blot analysis. The specificity of purified MeSMV-IgG was assessed by antigen-coated plate (ACP) ELISA using dilutions of infected and healthy plants (35). An aliquot of the $\operatorname{IgG}$ was conjugated with alkaline phosphatase using the glutaraldehyde two-step method and DAS-ELISA was performed as previously detailed (23).

For the Western blot analysis, purified nucleocapsid preparations or total leaf protein extracts were separated by $10 \%$ SDS-PAGE and transferred to $0.45-\mu \mathrm{m}$ nitrocellulose parablot NCP membranes (Macherey-Nagel, Duren, Germany) as described (36). Purified IgGs diluted $1: 1000$ in TBS-Tween $+7 \%$ dried skimmed milk were used as primary antibody, and anti-rabbit IgG conjugated with horseradish peroxidase (Sigma-Aldrich, St. Louis; dilution 1:5000 in TBS-Tween + $7 \%$ dried skimmed milk) was used as the secondary antibody. Super Signal West Pico Chemiluminescent substrate (Pierce, Rockford, IL) was used following the manufacturer's instructions to detect the presence of bound secondary antibodies.
RNA extraction, cDNA cloning, and sequence analyses. Total RNA was extracted from purified nucleocapsids using TRIZOL reagent (Invitrogen, Carlsbad, CA) according to the manufacturer's instructions. The Universal RiboClone Synthesis System (Promega Corp., Madison, WI) was used to obtain complementary DNA (cDNA) following the protocol provided by the manufacturer for first- and second-strand synthesis. A step including adaptor ligation and further polymerase chain reaction (PCR) amplification of the cDNA was performed as previously described (37). Selected PCR fragments were purified (Geneclean; qBiogene, Irvine, CA) and cloned in pGEM-T easy vector (Promega Corp.), and white colonies were screened by PCR with M13 forward and reverse primers. Positive colonies were grown in $4 \mathrm{ml}$ of Luria-Bertani with ampicillin at $0.05 \mathrm{mg} / \mathrm{ml}$, and plasmids were purified with the QIAprep spin Miniprep kit (Qiagen, Hilden, Germany). Plasmid inserts were sequenced using the dideoxy chain terminator method (25).

In order to obtain the full-length $S$ segment sequence, reverse transcription on purified viral RNAs was performed using the Thermoscript reverse-transcription (RT)-PCR System (Invitrogen) using random hexamers to prime cDNA synthesis. PCR was then performed using primers designed from initial S-segment genomic fragment sequences (Table 2). Selected PCR products were purified (Qiagen), cloned in pGEM-T Easy, and sequenced. The $\mathrm{S}$ segment $5^{\prime}$ and $3^{\prime}$ ends were cloned using the oligonucleotide $\mathrm{J} 13$ generic for Tospovirus ends as previously described (6) and internal specific primers (Table 2).

Clustal X version 1.81 was used for multiple sequence alignments (32). Statistical significance was calculated by performing 100 replications of bootstrap resampling of the original alignment using SEQBOOT. Phylogenetic trees were constructed with the PROTML algorithm in the Phylip version 3.6 (10) using the Dayhoff substitution matrix, one randomized sequence-input order, the global rearrangement option, and a mixed heterogeneity among sites variation model (one invariable plus six Gamma rates). TREEPUZZLE 5.0 (30) was used to estimate the relative rate for each category. Trees were

Table 2. List of Melon severe mosaic virus (MeSMV) primers used to complete the small (S) RNA sequence and for MeSMV detection by reverse-transcription polymerase chain reaction (primers MeSMV-2490-F and MeSMV-2900-R)

\begin{tabular}{ll}
\hline Primer name & \multicolumn{1}{c}{ Sequence } \\
\hline MeSMV-2490-F & $5^{\prime}$ tgctgaggattgtgcatacatt $3^{\prime}$ \\
MeSMV-2900-R & $5^{\prime}$ gggatcacaatcaaaaaatcaaaac 3' \\
MeSMV-2510-R & $5^{\prime}$ tggataatgatcaactgg $3^{\prime}$ \\
MeSMV-1380-F & $5^{\prime}$ gtcttcagcctccagagc $3^{\prime}$ \\
MeSMV-1020-R & $5^{\prime}$ cctaaacagggtaagttt $3^{\prime}$ \\
\hline
\end{tabular}

Table 1. Partial host range analysis of Melon severe mosaic virus ${ }^{\mathrm{a}}$

\begin{tabular}{|c|c|c|c|c|c|}
\hline \multirow[b]{2}{*}{ Family } & \multirow[b]{2}{*}{ Species } & \multicolumn{2}{|c|}{ Symptoms } & \multicolumn{2}{|c|}{ ELISA results } \\
\hline & & Inoculated leaves & Systemic & Local & Systemic \\
\hline \multirow[t]{13}{*}{ Solanaceae } & Datura stramonium & cll & 0 & + & - \\
\hline & Capsicum annum cv. Q.A. & cll & 0 & + & _- \\
\hline & C. chinense 152225 & 0 & 0 & - & - \\
\hline & Solanum lycopersicum cv. York & 0 & 0 & - & - \\
\hline & S. lycopersicum cv. Marmande & 0 & 0 & - & - \\
\hline & Nicotiana clevelandii & nll & Deformation/mosaic & + & + \\
\hline & N. megalosiphon & nll & Necrosis/deformation & - & + \\
\hline & N. rustica & 0 & 0 & + & - \\
\hline & N. tabacum cv. White Burley & $\mathrm{cll} / \mathrm{nll}$ & 0 & + & _- \\
\hline & N. glutinosa & nll & 0 & - & - \\
\hline & $N$. benthamiana & $\mathrm{cll} / \mathrm{nll}$ & Mosaic/deformation & + & + \\
\hline & Emilia sonchifolia & 0 & Chlorotic spot & + & + \\
\hline & Petunia $\times$ hybrida & nll & 0 & - & - \\
\hline \multirow[t]{3}{*}{ Cucurbitaceae } & Cucurbita pepo cv. Genovese & 0 & 0 & _- & _ \\
\hline & Cucumis melo & cll & Mosaic/deformation & + & + \\
\hline & Cucumis sativus & 0 & 0 & - & - \\
\hline Apocynaceae & Vinca rosea & 0 & 0 & - & - \\
\hline Labiatae & Ocimum basilicum & 0 & 0 & - & - \\
\hline Leguminosae & Phaseolus vulgaris cv. Saxa & 0 & 0 & - & - \\
\hline \multirow[t]{2}{*}{ Chenopodiaceae } & Chenopodium quinoa & 0 & 0 & - & - \\
\hline & Chenopodium amaranticolor & 0 & 0 & - & - \\
\hline \multirow[t]{2}{*}{ Amaranthaceae } & Beta vulgaris & $\mathrm{cll} / \mathrm{nll}$ & 0 & + & - \\
\hline & Gomphrena globosa & 0 & 0 & + & - \\
\hline
\end{tabular}

${ }^{a}$ Three individual plants for each species tested were mechanically inoculated when their first true leaves were fully expanded using leaf sap from symptomatic Nicotiana benthamiana and Cucumis melo leaves collected 2 weeks post inoculation. Host range results are based on visual evaluation and confirmed by double-antibody sandwich enzyme-linked immunosorbent assay (DAS-ELISA) results (visual evaluation was the same for each of the three plants and a mixed sample for each species was evaluated by DAS-ELISA). Cll = chlorotic local lesion; nll $=$ necrotic local lesion; $0=$ no symptom; + and - symbols correspond to infected/healthy ratio $(\mathrm{I} / \mathrm{H})$ of absorbance values above or below 3 in DAS-ELISA. 
generated with TreeView (19). Amino acid sequences of the other Tospovirus spp. used for the analysis were taken from GenBank, EMB, DDBJ, and PDB databases. RNA secondary structures were predicted using the MFold web server (41).

Survey of Mexican cucurbits crops. In February 2008, a survey of cucurbit crops across Mexico was carried out in four different regions, ranging from Sinaloa in the northwest to the state of Chiapas in the south. In all, 147 plants showing possible virus-caused symptoms (including $C$. melo, Cucurbita pepo, Cucumis sativus, and Citrullus lanatus) were collected and analyzed throughout the growing season (February to May) for the presence of the new Tospovirus sp. by using MeSMVspecific lateral flow (LF) devices. Commercial LF devices were prepared by Agdia from our nucleocapsid antibodies and used for the field survey. Symptomatic plant development stage ranged from flowering to ripe fruit ready for harvest. For confirmation of the serological analysis, RT-PCR was carried out on 30 RNA samples extracted from leaves as described above using the oligonucleotides MeSMV2490F and MeSMV-2900R (Table 2), with 30 cycles of PCR using a denaturing step of $30 \mathrm{~s}$ at $94^{\circ} \mathrm{C}$, an annealing step at $55^{\circ} \mathrm{C}$ for $30 \mathrm{~s}$, and a step for polymerase activity at $72^{\circ} \mathrm{C}$ for $20 \mathrm{~s}$. Ten samples (including positives and negatives by LF) were also analyzed by DAS-ELISA for further validation.

\section{RESULTS}

Virion morphology, symptoms, and partial host range. Enveloped pleomorphic particles with features typical for members of the Tospovirus genus were observed by electron microscopy of leaf extracts of symptomatic melon plants. Similar particles were seen from plants showing a variety of symptoms, including an early onset of mosaic and leaf blistering symptoms on honeydew melon leaves (Fig. 1A); advanced blistering, mosaic, and leaf deformation on honeydew melon (Fig.

1B); necrotic lesions on mature honeydew melon (Fig. 1C); and immature honeydew fruit exhibiting necrotic fruit splitting (Fig. 1D). No other virus-like particles were observed or detected by other methods, including DAS-ELISA, for the most common cucumo- and potyviruses present in the region, such as Papaya ringspot virus (PRSV), Watermelon mosaic virus (WMV), Zucchini yellow mosaic (ZYMV), and Cucumber mosaic virus (CMV). When leaves were used for mechanical inoculation of $N$. benthamiana and Cucumis melo plants, symptoms were clear on inoculated plants by 7 days post inoculation (dpi). In fact, severe symptoms similar to those seen on the original diseased plants, such as mosaic, leaf deformation, and growth arrest, were observed.

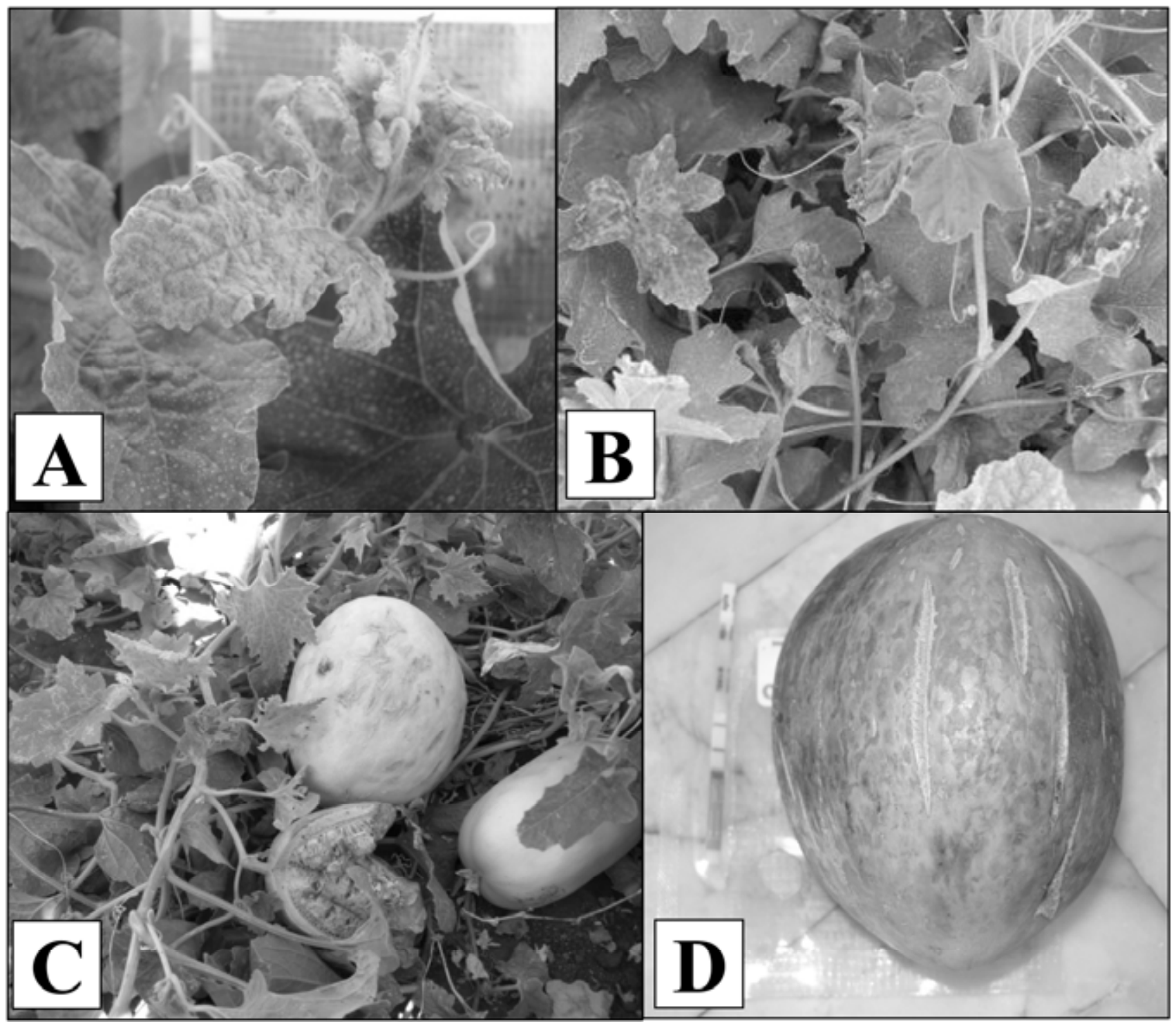

Fig. 1. Symptoms of melon plants infected with Melon severe mosaic virus. Photographs were taken in February 2007 and February 2008 in a field in Guerrero State, Mexico. A, Early onset of mosaic and leaf blistering symptoms on honeydew melon leaves; B, advanced blistering, mosaic, and leaf deformation on honeydew melon; $\mathbf{C}$, necrotic lesions on mature honeydew melon; and $\mathbf{D}$, and immature honeydew fruit exhibiting necrotic fruit splitting. 
MeSMV was able to systemically infect plants of $N$. benthamiana, $N$. megalosiphon, Datura stramonium, and $N$ clevelandii, and caused deformation, mosaic, or necrosis; the virus infection caused also chlorotic spots on Emilia sonchifolia plants. DAS-ELISA confirmed the presence of MeSMV in inoculated and uninoculated leaves (Table 1). Interestingly, MeSMV did not infect the other two Cucurbitaceae spp. present in the host range study: $C$. sativus and Cucurbita pepo cv. Genovese.

Virus purification and serology. Typical Tospovirus sp.-like nucleocapsids were observed by electron microscopy in negatively stained purified MeSMV nucleocapsid preparations. The molecular weight of the $\mathrm{N}$ protein was estimated to be about 30 kDa by SDS-PAGE (Fig. 2).

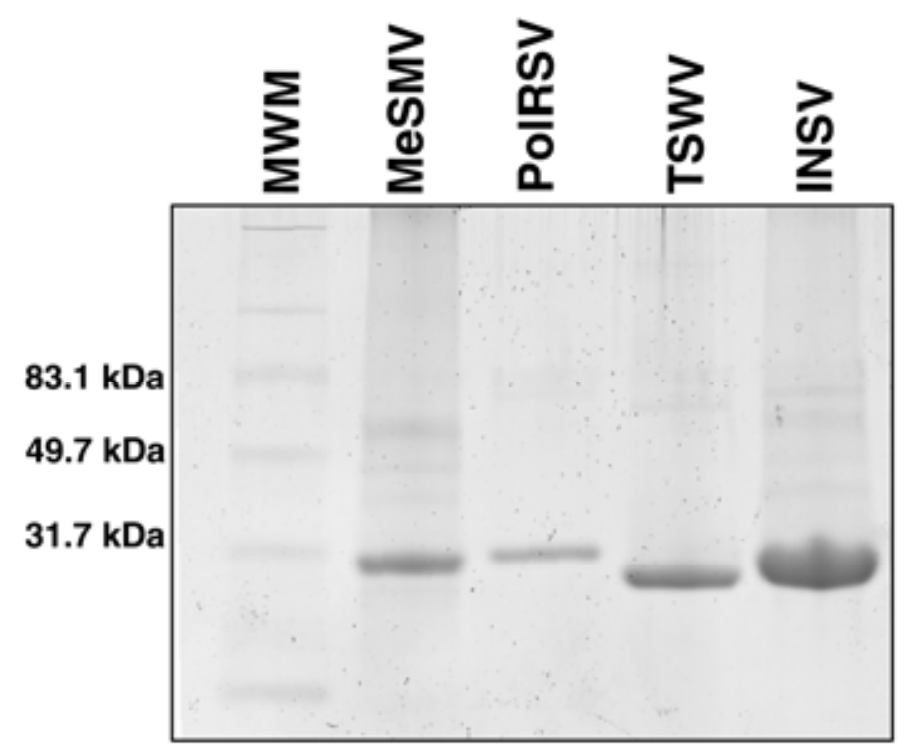

Fig. 2. Coomassie stained $10 \%$ polyacrylamide gel showing purified nucleocapsid proteins of Melon severe mosaic virus (MeSMV), Impatiens necrotic spot virus (INSV), Polygonum ringspot virus (PolRSV), and Tomato spotted wilt virus (TSWV). MWM, molecular weight markers. Numbers at left indicate positions for proteins of the respective size $\left(\times 10^{-3}\right)$.
In DAS-ELISA, the MeSMV antibody did not cross-react with other Tospovirus antigens tested, whereas some crossreactivity was shown for a number of $\mathrm{To}$ spovirus antigens (including a very low value for MeSMV) when anti-CSNV and anti-TCSV antibodies were used (Fig. 3). Western blot analysis using anti-MeSMV antibodies on total soluble proteins extracted from infected leaves confirmed the serological reactions seen in DAS-ELISA. MeSMV antibodies showed a strong reaction with its corresponding infected plant but also a positive reaction with TSWVinfected plants (Fig. 4). However, TSWV antibodies (A353) did not show a similar cross-reaction with MeSMV in Western blot (Fig. 4).

Sequence analysis and virus phylogenetic and taxonomic placement. The MeSMV complete nucleotide sequence of the S RNA was obtained from a number of overlapping clones (National Center for Biotechnology Information [NCBI] accession no. EU275149). The S RNA was 3,283 nucleotides (nt) and contained two open reading frames (ORF). The first ORF, from nucleotide 81 to 1,448 , encoded the NSs protein (455 amino acids [aa]) with an estimated molecular weight of $50.9 \mathrm{kDa}$. The second ORF, from nucleotide 2,336 to 3,124 , encoded the $\mathrm{N}$ protein (262 aa) with an estimated molecular weight of 29.5 $\mathrm{kDa}$, which was similar to the $\mathrm{N}$ protein molecular weight estimate based on electrophoretic mobility of the purified nucleocapsids. The noncoding intergenic

DAS-ELISA

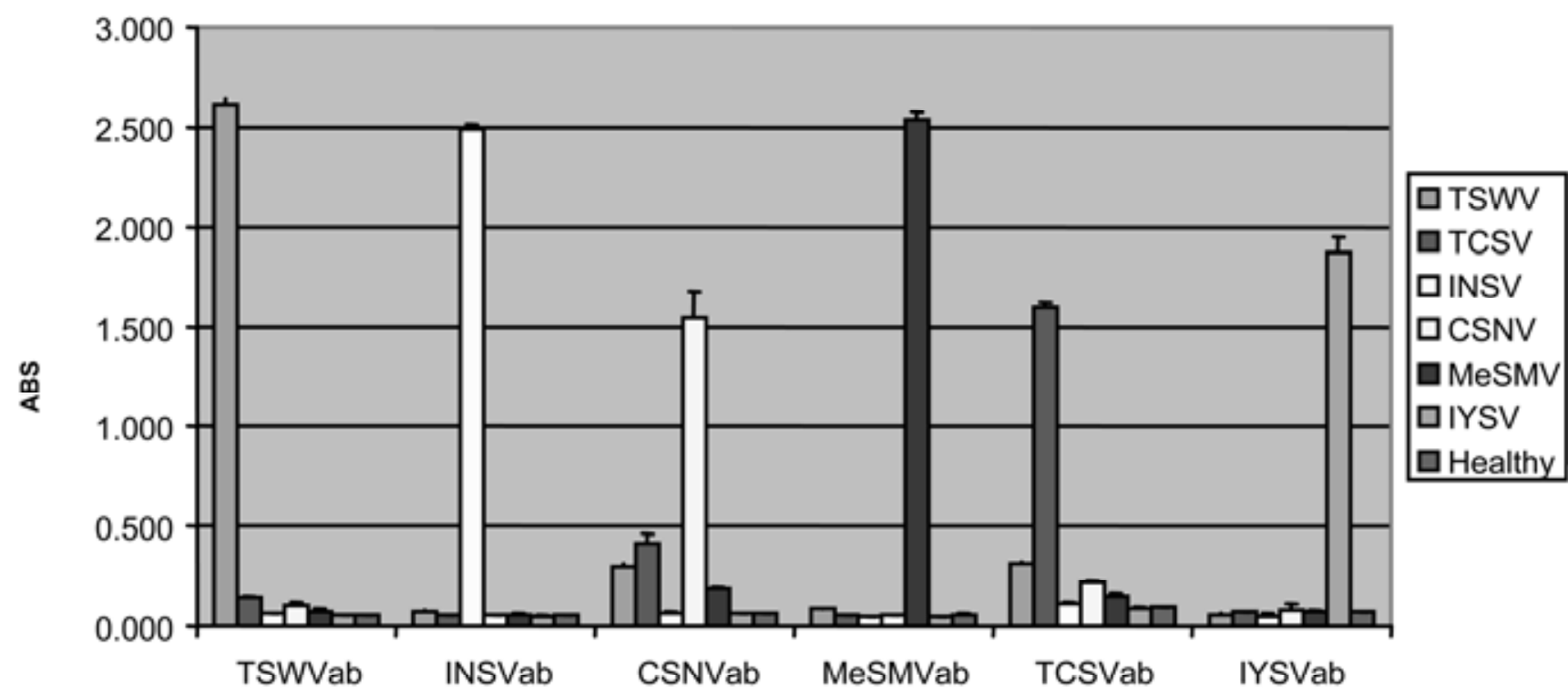

Antisera

Fig. 3. Serological reactions in double-antibody sandwich enzyme-linked immunosorbent assay among six Tospovirus spp. using antisera made against the nucleocapsids of each virus (X axis) and, as antigens, Nicotiana benthamiana plants infected with each of the homologous viruses detailed in the legend. Numbers in the $\mathrm{Y}$ axis indicate absorbance values at $405 \mathrm{~nm}$. Error bars represent standard deviation calculated from four replicates for each sample. Viruses: Tomato spotted wilt virus (TSWV) BAA03025, Tomato chlorotic spot virus (TCSV) AAG23654, Impatiens necrotic spot virus (INSV) AAA47974, Chrysanthemum stem necrosis virus (CSNV) AAF04197, Melon severe mosaic virus (MeSMV), and Iris yellow spot virus (IYSV) AAF75556. 
region (IR) was $888 \mathrm{nt}$, rich in $\mathrm{A}$ and $\mathrm{U}$ residues (74\%), and predicted to form the typical hairpin secondary structure (not shown). The sequences of a $1-\mathrm{kb}$ fragment of the M RNA and a $1.5-\mathrm{kb}$ fragment of the L RNA were also obtained and deposited in GenBank (NCBI accession nos. FJ157984 and FJ157985, respectively).

To clarify the taxonomic position of MeSMV, the $\mathrm{N}$ protein and a part of the glycoprotein $(\mathrm{G})$ precursor protein (from amino acid position 430 to 917 when aligned to TSWV $\mathrm{G}$ precursor protein, therefore covering part of the Gc region) were compared with corresponding regions of other known Tospovirus spp. For the N protein, the highest similarity was with CSNV (67\%; Table 3). For partial G protein, the highest similarity was with TSWV (72\%; Table 4). A phylogenetic tree based on Tospovirus N proteins (Fig. 5A) showed the presence of four main clusters: one with viruses distributed mainly in North and South America, assuming that TSWV and Impatiens necrotic spot virus (INSV) are likely of American origin; a second cluster of the tospoviral species from Asia; a third cluster containing Iris yellow spot virus (IYSV), Polygonum ring spot virus (PolRSV), and Tomato yellow ring virus (TYRV), three Tospovirus spp. likely of Middle-Eastern origin (12); and a fourth cluster composed of Peanut yellow spot virus (PYSV) and Peanut chlorotic fanspot virus (PCFV), two viruses with possible origin in south-eastern Asia. MeSMV is in the clade of American species but in a separate branch. The consensus tree relative to $\mathrm{G}$ protein alignments (Fig. 5B) showed that MeSMV clusters with "new world" Tospovirus spp.

Survey of Mexican cucurbits crops. Following the initial identification of MeSMV as a new Tospovirus sp., a survey to assess its incidence and distribution in several melon-growing areas of Mexico was undertaken. Of the 147 symptomatic plants that were tested, MeSMV was found in melon, zucchini, cucumber, and watermelon plants (Table 5). The results from LF were confirmed when validated by both DAS-ELISA (carried out on 10 samples) and RT-PCR (carried out on 30 samples).

Given the surprising results for the fieldinfected cucumber sample, we checked whether significant molecular differences were present in the cucumber isolate when compared with the melon isolate we had cloned and sequenced; the RT-PCR product obtained from the same sample was sequenced directly, confirming $99 \%$ identity with the MeSMV sequence deposited in GenBank (not shown). In summary, the majority of the 147 plants (66\%) from various states in Mexico were MeSMV positive by $\mathrm{LF}$, indicating its relatively wide geographic distribution and presence in different cucurbit crops (Table 5).

\section{DISCUSSION}

Cantaloupe is one of the most economically important cucurbit crops in Mexico. PRSV, WMV, ZYMV, and CMV are the major viruses reported in Mexican cucurbit crops (8). Squash leaf curl virus is also prevalent in some parts of Mexico $(3,5,22)$ and, recently, Cucurbit yellow

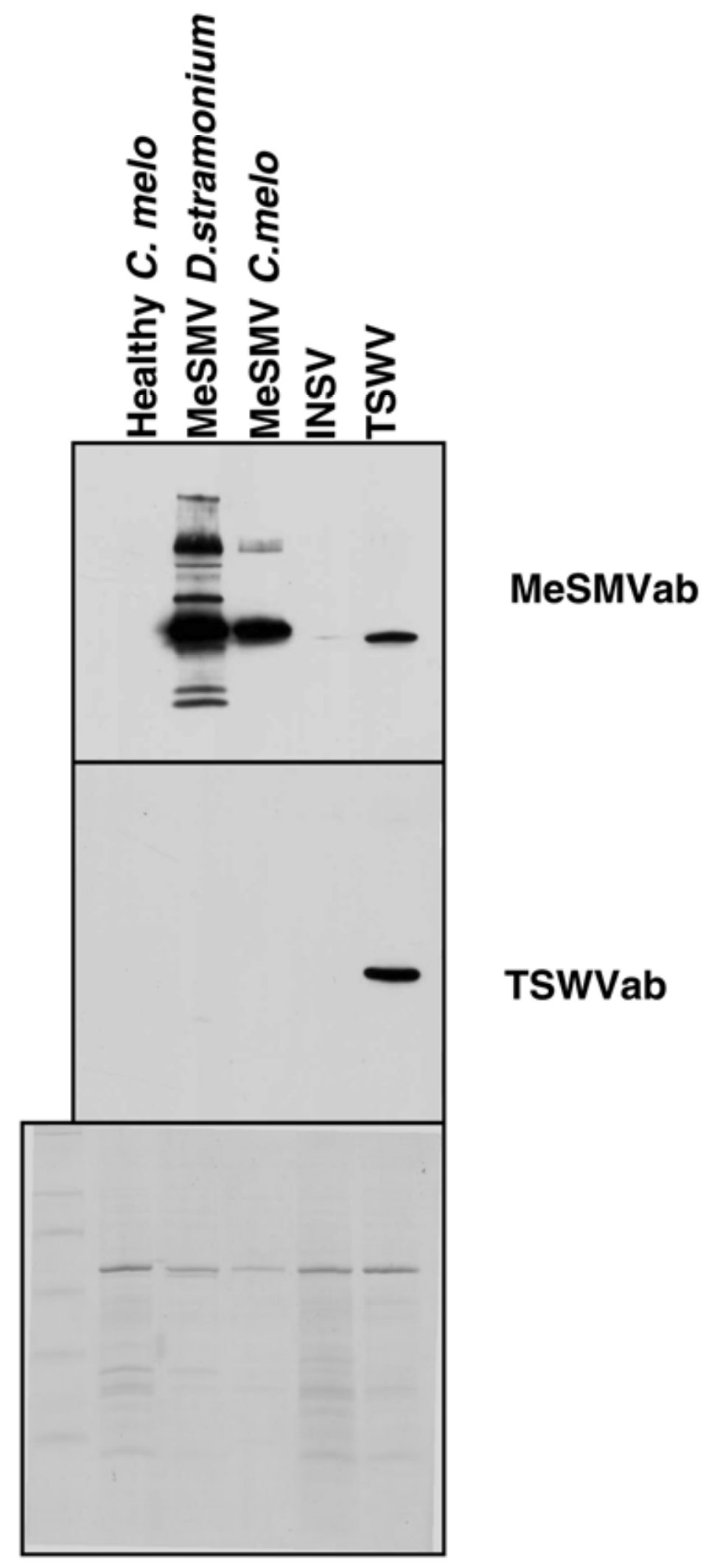

Fig. 4. Western blot analysis of leaf extracts from Nicotiana benthamiana plants infected with Tomato spotted wilt virus (TSWV), Impatiens necrotic spot virus (INSV), and Melon severe mosaic virus (MeSMV) using antibodies against the nucleocapsid of TSWV and MeSMV. Lower panel is a Coomassie stain of the gel to show the amount of total protein loaded. 
stunting disorder virus has been reported (4).

In recent years, a new disease has been spreading in cucurbits crops, especially on melon and watermelon, sometimes reducing production by as much as 20 to $30 \%$. Our study showed that a new Tospovirus sp. is associated with this new disease. Specificity of the host range and serological and N-protein relationship indicate that MeSMV is a new Tospovirus sp. It was somewhat surprising to confirm MeSMV infection of zucchini and cucumber in the open fields, because plants of these species did not get infected in our host range ex- periments. This could be due to several reasons, including different cultivars, mechanical versus thrips transmission, or biological diversity of the virus isolates from different hosts, even though no evidence of such occurrence was shown for other Tospovirus spp. (33). Nevertheless, MeSMV has a broad host range among cucurbits and could represent a new virus problem in the Americas.

The $\mathrm{N}$ protein amino acid sequence is an important criterion to classify Tospovirus spp. $(7,9,15,21)$. Less than $80 \%$ similarity is considered the limit to separate different species (15). Analysis of the S RNA ge- nomic segment showed that maximum similarity between the MeSMV N protein amino acid sequence and those of other Tospovirus spp. is $67 \%$ with CSNV, well below the threshold and, thus, supporting the idea that MeSMV is a distinct Tospovirus sp.

Like our host range and sequence analyses, serological analysis for Tospovirus $\mathrm{N}$ proteins showed that MeSMV is a distinct Tospovirus sp. Our Western blot analysis showed that MeSMV antibodies crossreacted with TSWV $\mathrm{N}$ proteins but only when tested under these denaturing conditions. This warns against using this tech-

Table 3. Similarity based on the alignment of the nucleocapsid protein of 22 Tospovirus spp. ${ }^{\mathrm{a}}$

\begin{tabular}{|c|c|c|c|c|c|c|c|c|c|c|c|c|c|c|c|c|c|c|c|c|c|c|}
\hline Virus & GloxRSV & $\mathrm{CaCV}$ & TomNecrV & GBNV & PBNV & WBNV & WSMoV & CCSV & MYSV & PhySMV & PolRSV & TYRV & IYSV & CSNV & ZLCV & GRSV & TCSV & TSWV & MeSMV & INSV & PCFV & PYSV \\
\hline GloxRSV & 1.000 & 1.000 & 0.974 & 0.888 & 0.887 & 0.841 & 0.886 & 0.707 & 0.629 & 0.635 & 0.488 & 0.528 & 0.509 & 0.270 & 0.277 & 0.283 & 0.282 & 0.294 & 0.288 & 0.313 & 0.274 & 0.238 \\
\hline $\mathrm{CaCV}$ & $\ldots$ & 1.000 & 0.974 & 0.888 & 0.887 & 0.841 & 0.886 & 0.709 & 0.633 & 0.638 & 0.493 & 0.533 & 0.514 & 0.277 & 0.284 & 0.290 & 0.288 & 0.301 & 0.286 & 0.319 & 0.271 & 0.235 \\
\hline TomNecrV & $\ldots$ & $\ldots$ & 1.000 & 0.880 & 0.880 & 0.845 & 0.890 & 0.684 & 0.631 & 0.637 & 0.491 & 0.531 & 0.516 & 0.272 & 0.280 & 0.286 & 0.284 & 0.302 & 0.286 & 0.306 & 0.282 & 0.243 \\
\hline GBNV & $\ldots$ & $\ldots$ & $\ldots$ & 1.000 & 0.996 & 0.883 & 0.907 & 0.691 & 0.608 & 0.608 & 0.469 & 0.489 & 0.452 & 0.272 & 0.295 & 0.281 & 0.270 & 0.272 & 0.309 & 0.306 & 0.256 & 0.227 \\
\hline PBNV & $\ldots$ & $\ldots$ & $\ldots$ & $\ldots$ & 1.000 & 0.886 & 0.906 & 0.691 & 0.613 & 0.613 & 0.473 & 0.493 & 0.457 & 0.275 & 0.298 & 0.284 & 0.272 & 0.275 & 0.312 & 0.299 & 0.259 & 0.227 \\
\hline WBNV & $\ldots$ & $\ldots$ & $\ldots$ & $\ldots$ & $\ldots$ & 1.000 & 0.886 & 0.686 & 0.575 & 0.575 & 0.457 & 0.468 & 0.436 & 0.277 & 0.290 & 0.276 & 0.250 & 0.262 & 0.304 & 0.296 & 0.249 & 0.213 \\
\hline WSMoV & $\ldots$ & $\ldots$ & $\ldots$ & $\ldots$ & $\ldots$ & $\ldots$ & 1.000 & 0.703 & 0.610 & 0.615 & 0.475 & 0.500 & 0.459 & 0.273 & 0.305 & 0.296 & 0.256 & 0.259 & 0.311 & 0.306 & 0.247 & 0.246 \\
\hline CCSV & $\ldots$ & $\ldots$ & $\ldots$ & $\ldots$ & $\ldots$ & $\ldots$ & $\ldots$ & 1.000 & 0.630 & 0.630 & 0.486 & 0.530 & 0.484 & 0.260 & 0.282 & 0.262 & 0.222 & 0.254 & 0.278 & 0.245 & 0.200 & 0.192 \\
\hline MYSV & $\ldots$ & $\ldots$ & $\ldots$ & $\ldots$ & $\ldots$ & $\ldots$ & $\ldots$ & $\ldots$ & 1.000 & 0.992 & 0.524 & 0.527 & 0.536 & 0.316 & 0.309 & 0.300 & 0.288 & 0.304 & 0.299 & 0.299 & 0.201 & 0.197 \\
\hline PhySMV & $\ldots$ & $\ldots$ & $\ldots$ & $\ldots$ & $\ldots$ & $\ldots$ & $\ldots$ & $\ldots$ & $\ldots$ & 1.000 & 0.529 & 0.532 & 0.541 & 0.319 & 0.312 & 0.302 & 0.291 & 0.307 & 0.302 & 0.301 & 0.201 & 0.199 \\
\hline PolRSV & $\ldots$ & $\ldots$ & $\ldots$ & $\ldots$ & $\ldots$ & $\ldots$ & $\ldots$ & $\ldots$ & $\ldots$ & $\ldots$ & 1.000 & 0.825 & 0.709 & 0.377 & 0.385 & 0.382 & 0.371 & 0.348 & 0.343 & 0.311 & 0.240 & 0.261 \\
\hline TYRV & $\ldots$ & $\ldots$ & $\ldots$ & $\ldots$ & $\ldots$ & $\ldots$ & $\ldots$ & $\ldots$ & $\ldots$ & $\ldots$ & $\ldots$ & 1.000 & 0.722 & 0.371 & 0.410 & 0.412 & 0.390 & 0.367 & 0.356 & 0.300 & 0.223 & 0.244 \\
\hline IYSV & $\ldots$ & $\ldots$ & $\ldots$ & $\ldots$ & $\ldots$ & $\ldots$ & $\ldots$ & $\ldots$ & $\ldots$ & $\ldots$ & $\ldots$ & $\ldots$ & 1.000 & 0.332 & 0.330 & 0.350 & 0.353 & 0.405 & 0.338 & 0.308 & 0.190 & 0.236 \\
\hline CSNV & $\ldots$ & $\ldots$ & $\ldots$ & $\ldots$ & $\ldots$ & $\ldots$ & $\ldots$ & $\ldots$ & $\ldots$ & $\ldots$ & $\ldots$ & $\ldots$ & $\ldots$ & 1.000 & 0.814 & 0.776 & 0.781 & 0.782 & 0.670 & 0.580 & 0.254 & 0.268 \\
\hline ZLCV & $\ldots$ & $\ldots$ & $\ldots$ & $\ldots$ & $\ldots$ & $\ldots$ & $\ldots$ & $\ldots$ & $\ldots$ & $\ldots$ & $\ldots$ & $\ldots$ & $\ldots$ & $\ldots$ & 1.000 & 0.775 & 0.744 & 0.708 & 0.642 & 0.571 & 0.235 & 0.230 \\
\hline GRSV & $\ldots$ & $\ldots$ & $\ldots$ & $\ldots$ & $\ldots$ & $\ldots$ & $\ldots$ & $\ldots$ & $\ldots$ & $\ldots$ & $\ldots$ & $\ldots$ & $\ldots$ & $\ldots$ & $\ldots$ & 1.000 & 0.863 & 0.761 & 0.636 & 0.587 & 0.253 & 0.257 \\
\hline TCSV & $\ldots$ & $\ldots$ & $\ldots$ & $\ldots$ & $\ldots$ & $\ldots$ & $\ldots$ & $\ldots$ & $\ldots$ & $\ldots$ & $\ldots$ & $\ldots$ & $\ldots$ & $\ldots$ & $\ldots$ & $\ldots$ & 1.000 & 0.785 & 0.638 & 0.564 & 0.235 & 0.260 \\
\hline TSWV & $\ldots$ & $\ldots$ & $\ldots$ & $\ldots$ & $\ldots$ & $\ldots$ & $\ldots$ & $\ldots$ & $\ldots$ & $\ldots$ & $\ldots$ & $\ldots$ & $\ldots$ & $\ldots$ & $\ldots$ & $\ldots$ & $\ldots$ & 1.000 & 0.570 & 0.598 & 0.230 & 0.239 \\
\hline MeSMV & $\ldots$ & $\ldots$ & $\ldots$ & $\ldots$ & $\ldots$ & $\ldots$ & $\ldots$ & $\ldots$ & $\ldots$ & $\ldots$ & $\ldots$ & $\ldots$ & $\ldots$ & $\ldots$ & $\ldots$ & $\ldots$ & $\ldots$ & $\ldots$ & 1.000 & 0.569 & 0.240 & 0.281 \\
\hline INSV & $\ldots$ & $\ldots$ & $\ldots$ & $\ldots$ & $\ldots$ & $\ldots$ & $\ldots$ & $\ldots$ & $\ldots$ & $\ldots$ & $\ldots$ & $\ldots$ & $\ldots$ & $\ldots$ & $\ldots$ & $\ldots$ & $\ldots$ & $\ldots$ & $\ldots$ & 1.000 & 0.232 & 0.244 \\
\hline PCFV & $\ldots$ & $\ldots$ & $\ldots$ & $\ldots$ & $\ldots$ & $\ldots$ & $\ldots$ & $\ldots$ & $\ldots$ & $\ldots$ & $\ldots$ & $\ldots$ & $\ldots$ & $\ldots$ & $\ldots$ & $\ldots$ & $\ldots$ & $\ldots$ & $\ldots$ & $\ldots$ & 1.000 & 0.708 \\
\hline PYSV & $\ldots$ & $\ldots$ & $\ldots$ & $\ldots$ & $\ldots$ & $\ldots$ & $\ldots$ & $\ldots$ & $\ldots$ & $\ldots$ & $\ldots$ & $\ldots$ & $\ldots$ & $\ldots$ & $\ldots$ & $\ldots$ & $\ldots$ & $\ldots$ & $\ldots$ & $\ldots$ & $\ldots$ & 1.000 \\
\hline
\end{tabular}

${ }^{a}$ Virus acronyms: Gloxinia ringspot virus (GloxRSV) AAQ83791, Capsicum chlorosis virus (CaCV) ABC86907, Tomato necrosis virus (TomNecrV) AAT68025, Groundnut bud necrosis virus (GBNV) AAR24021, Peanut bud necrosis virus (PBNV) AAM76063, Watermelon bud necrosis virus (WBNV) ABD39046, Watermelon silver mottle virus (WSMoV) AAW64930, Calla lily chlorotic spot (CCSV) AAW58115, Melon yellow severe virus (MYSV) BAB79455, Physalis severe mosaic virus (PhySMV) AAD34201, Polygonum ringspot virus (PolRSV) EF445397, Tomato yellow ring virus (TYRV) ABF59486, Iris yellow spot virus (IYSV) AAF75556, Chrysanthemum stem necrosis virus (CSNV)AAF04197, Zucchini lethal chlorosis virus (ZLCV) AAF04198, Groundnut ring spot virus (GRSV) AAF25255, Tomato chlorotic spot virus (TCSV) AAG23654, Tomato spotted wilt virus (TSWV) BAA03025, Melon severe mosaic virus (MeSMV), Impatiens necrotic spot virus (INSV) AAA47974, Peanut chlorotic fanspot virus (PCFV) AAC99405, and Peanut yellow spot virus (PYSV) AAB94022. Similarity values were obtained by the software PROTDIST as detailed in the material and methods section. In bold are the values relative to MeSMV nucleocapsid alignement with the other Tospovirus spp.

Table 4. Similarities between a fragment of the glyco- protein of 15 Tospovirus spp. ${ }^{\mathrm{a}}$

\begin{tabular}{|c|c|c|c|c|c|c|c|c|c|c|c|c|c|c|c|}
\hline Virus & CSNV & TSWV & GRSV & TCSV & ZLCV & INSV & MeSMV & GTV & $\mathrm{CaCV}$ & GBNV & WSMoV & TZSV & MYSV & IYSV & PolRSV \\
\hline CSNV & 1.000 & 0.907 & 0.862 & 0.865 & 0.874 & 0.708 & 0.694 & 0.393 & 0.384 & 0.394 & 0.385 & 0.388 & 0.405 & 0.403 & 0.420 \\
\hline TSWV & $\ldots$ & 1.000 & 0.867 & 0.883 & 0.870 & 0.719 & 0.720 & 0.398 & 0.395 & 0.401 & 0.414 & 0.402 & 0.419 & 0.412 & 0.424 \\
\hline GRSV & $\ldots$ & $\ldots$ & 1.000 & 0.975 & 0.831 & 0.706 & 0.715 & 0.406 & 0.389 & 0.399 & 0.414 & 0.398 & 0.403 & 0.411 & 0.403 \\
\hline TCSV & $\ldots$ & $\ldots$ & $\ldots$ & 1.000 & 0.844 & 0.712 & 0.710 & 0.407 & 0.390 & 0.394 & 0.410 & 0.399 & 0.403 & 0.411 & 0.403 \\
\hline ZLCV & $\ldots$ & $\ldots$ & $\ldots$ & $\ldots$ & 1.000 & 0.692 & 0.674 & 0.393 & 0.388 & 0.394 & 0.400 & 0.394 & 0.419 & 0.412 & 0.429 \\
\hline INSV & $\ldots$ & $\ldots$ & $\ldots$ & $\ldots$ & $\ldots$ & 1.000 & 0.670 & 0.399 & 0.398 & 0.397 & 0.395 & 0.394 & 0.406 & 0.384 & 0.411 \\
\hline MeSMV & $\ldots$ & $\ldots$ & $\ldots$ & $\ldots$ & $\ldots$ & $\ldots$ & 1.000 & 0.402 & 0.399 & 0.399 & 0.402 & 0.395 & 0.397 & 0.417 & 0.411 \\
\hline GTV & $\ldots$ & $\ldots$ & $\ldots$ & $\ldots$ & $\ldots$ & $\ldots$ & $\ldots$ & 1.000 & 0.929 & 0.918 & 0.903 & 0.770 & 0.726 & 0.741 & 0.746 \\
\hline $\mathrm{CaCV}$ & $\ldots$ & $\ldots$ & $\ldots$ & $\ldots$ & $\ldots$ & $\ldots$ & $\ldots$ & $\ldots$ & 1.000 & 0.905 & 0.881 & 0.764 & 0.745 & 0.738 & 0.727 \\
\hline GBNV & $\ldots$ & $\ldots$ & $\ldots$ & $\ldots$ & $\ldots$ & $\ldots$ & $\ldots$ & $\ldots$ & $\ldots$ & 1.000 & 0.930 & 0.791 & 0.738 & 0.759 & 0.733 \\
\hline WSMoV & $\ldots$ & $\ldots$ & $\ldots$ & $\ldots$ & $\ldots$ & $\ldots$ & $\ldots$ & $\ldots$ & $\ldots$ & $\ldots$ & 1.000 & 0.791 & 0.732 & 0.770 & 0.735 \\
\hline TZSV & $\ldots$ & $\ldots$ & $\ldots$ & $\ldots$ & $\ldots$ & $\ldots$ & $\ldots$ & $\ldots$ & $\ldots$ & $\ldots$ & $\ldots$ & 1.000 & 0.749 & 0.706 & 0.724 \\
\hline MYSV & $\ldots$ & $\ldots$ & $\ldots$ & $\ldots$ & $\ldots$ & $\ldots$ & $\ldots$ & $\ldots$ & $\ldots$ & $\ldots$ & $\ldots$ & $\ldots$ & 1.000 & 0.671 & 0.675 \\
\hline IYSV & $\ldots$ & $\ldots$ & $\ldots$ & $\ldots$ & $\ldots$ & $\ldots$ & $\ldots$ & $\ldots$ & $\ldots$ & $\ldots$ & $\ldots$ & $\ldots$ & $\ldots$ & 1.000 & 0.861 \\
\hline PolRSV & $\ldots$ & $\ldots$ & $\ldots$ & $\ldots$ & $\ldots$ & $\ldots$ & $\ldots$ & $\ldots$ & $\ldots$ & $\ldots$ & $\ldots$ & $\ldots$ & $\ldots$ & $\ldots$ & 1.000 \\
\hline
\end{tabular}

${ }^{a}$ Virus acronyms: Chrysanthemum stem necrosis virus (CSNV) AAF04197, Tomato spotted wilt virus (TSWV) BAA03025, Groundnut ring spot virus (GRSV) AAF25255, Tomato chlorotic spot virus (TCSV) AAG23654, Zucchini lethal chlorosis virus (ZLCV) AAF04198, Impatiens necrotic spot virus (INSV) AAA47974, Melon severe mosaic virus (MeSMV), Gloxinia tospovirus (GTV) (AAC15466.1), Capsicum chlorosis virus (CaCV) ABC86907, Groundnut bud necrosis virus (GBNV) AAR24021, Watermelon silver mottle virus (WSMoV) AAW64930, Tomato zonate spot virus (TZSV), Melon yellow severe virus (MYSV) BAB79455, Iris yellow spot virus (IYSV) AAF75556, and Polygonum ringspot virus (PolRSV) EF445397. Similarity values were obtained by the software PROTDIST as detailed in the material and methods section. In bold are the values relative to MeSMV nucleocapsid alignement with the other Tospovirus spp. 
nique for open-field diagnostic purposes. By contrast, the specificity of our MeSMV antibodies in DAS-ELISA well suits the requirements for a sensitive and specific diagnostic kit to process a large number of field samples.

The vector for MeSMV is not yet known, although western flower thrips (Frankliniella occidentalis), a known Tospovirus vector species, was present on MeSMV-infected plants. CSNV is transmitted by $F$. occidentalis and $F$. schultzei (1), whereas ZLCV (another cucurbitinfecting Tospovirus sp. from the Americas) is transmitted only by F. zucchini (17).

It is unknown exactly how long MeSMV has been present in Mexico because symp- toms are not always specific, and the presence of the most common cucurbit Potyvirus spp. (e.g., ZYMV) could have masked the presence of MeSMV. The widespread presence of MeSMV on different cucurbit crops and in different states of Mexico also suggests that MeSMV has already been established and, given the contiguous na-

Table 5. Survey of Mexican cucurbit crops in February 2008

\begin{tabular}{lcccc}
\hline & \multicolumn{4}{c}{ Number of MeSMV-positive samples over the number tested } \\
\cline { 2 - 5 } Locations in Mexico & Watermelon & Melon & Cucumber & Zucchini $^{\text {a }}$ \\
\cline { 2 - 6 } Puebla & $\ldots$ & $\ldots$ & $\ldots$ & $28 / 35$ \\
Guerrero, Michoacan de Ocampo & $\ldots$ & $43 / 55$ & $\ldots$ & $\ldots$ \\
Campeche, Chiapas and Jalisco & $15 / 30$ & $\ldots$ & $\ldots$ & $\ldots$ \\
Sinaloa & $\ldots$ & $\ldots$ & $1 / 2$ & $\ldots$ \\
Mexico & $\ldots$ & $\ldots$ & $\ldots$ & $13 / 25$ \\
\hline
\end{tabular}

a Samples were analyzed by later flow devices in the field, and a subset was confirmed to be infected by Melon severe mosaic virus (MeSMV) by reverse-transcription polymerase chain reaction and double-antibody sandwich enzyme-linked immunosorbent assay.

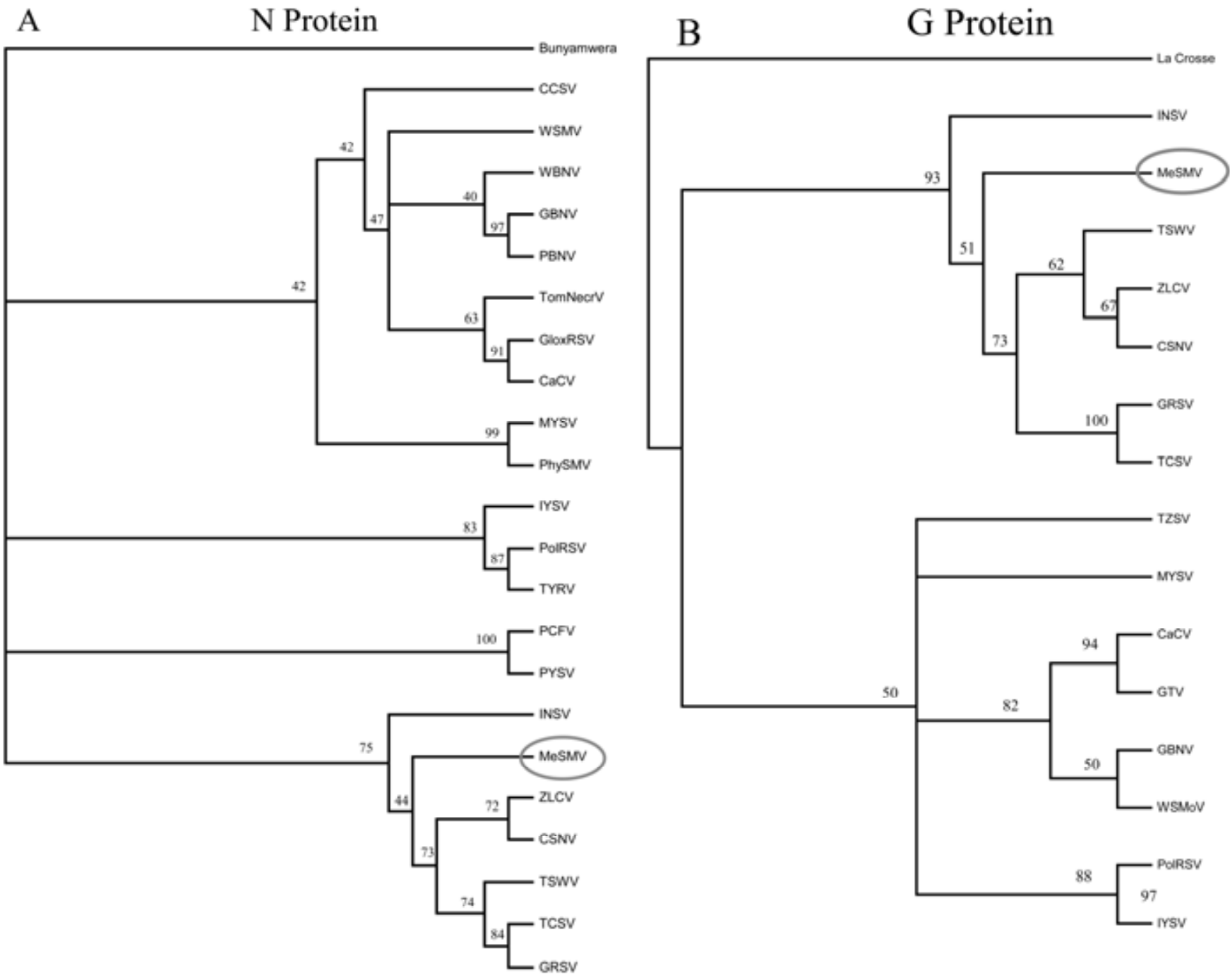

Fig. 5. Phylogenetic analysis of Melon severe mosaic virus (MeSMV) proteins. A, Consensus phylogenetic tree obtained from alignments of the nucleocapsid (N) protein sequences of 21 Tospovirus spp., including accepted and tentative species: Capsicum chlorosis virus (CaCV) ABC86907, Calla lily chlorotic spot (CCSV) AAW58115, Chrysanthemum stem necrosis virus (CSNV)AAF04197, Groundnut bud necrosis virus (GBNV) AAR24021, Gloxinia ringspot virus (GloxRSV) AAQ83791, Groundnut ring spot virus (GRSV) AAF25255, Iris yellow spot virus (IYSV) AAF75556, Melon yellow severe virus (MYSV) BAB79455, Peanut bud necrosis virus (PBNV) AAM76063, Peanut chlorotic fanspot virus (PCFV) AAC99405, Polygonum ringspot virus (PolRSV) EF445397, Physalis severe mosaic virus (PhySMV) AAD34201, Peanut yellow spot virus (PYSV) AAB94022, Tomato chlorotic spot virus (TCSV) AAG23654, Tomato necrosis virus (TomNecrV) AAT68025, Tomato spotted wilt virus (TSWV) BAA03025, Tomato yellow ring virus (TYRV) ABF59486, Watermelon bud necrosis virus (WBNV) ABD39046, Watermelon silver mottle virus (WSMoV) AAW64930, Zucchini lethal chlorosis virus (ZLCV) AAF04198, Impatiens necrotic spot virus (INSV) AAA47974, and Bunyamwera virus NP_047213. PBNV is now considered a strain of GBNV (10). B, Consensus phylogenetic tree obtained from alignments of G protein sequence fragments of 15 Tospovirus spp. or isolates. Branches at nodes with a bootstrap value <50 have been collapsed to politomy. Viruses: La crosse virus (AAB62803.1), GBNV (NP_619703.1), Gloxinia tospovirus (GTV) (AAC15466.1), GRSV (AAU10600.2), INSV (ABD93457.1), MYSV (YP_717935.1), PolRSV (ABX65310.1), TCSV (AAU10599.2), Tomato zonate spot virus (TZSV) (YP_001740046.1), TSWV (AAV28056.1), WSMoV (NP_620767.1), ZLCV (BAF62147.1), IYSV (AAL62023.1), CaCV (YP_717926.1), and CSNV (BAF62146.1). 
ture of cucurbit cultivation between Mexico and the southern states of the United States, a close inspection of cucurbit crops in the southern United States to determine the presence of MeSMV should be undertaken.

\section{ACKNOWLEDGMENTS}

We thank R. Lenzi and C. Perrone for technical assistance and Agdia (Elkhart, IN) for the development of a lateral flow test kit.

\section{LITERATURE CITED}

1. Bezerra, I. C., Resende, R., Pozzer, L., Nagata, T., Kormelink, R., and De Avila, A. C. 1999. Increase of tospoviral diversity in Brazil with the identification of two new Tospovirus species, one from chrysanthemum and one from zucchini. Phytopathology 89:823-830.

2. Bucher, E., Sijen, T., de Haan, P., Goldbach, R., and Prins, M. 2003. Negative-strand Tospoviruses carry a gene for gene silencing at analogous genomic positions. J. Virol. 77:1329-1336.

3. Brown, J. K., and Bird, J. 1992. Whiteflytransmitted geminiviruses in the americas and the Caribbean Basin: Past and present. Plant Dis. 76:220-225.

4. Brown, J. K., Guerrero, J. C., Matheron, M., Olsen, M., and Idris, A.M. 2007. Widespread outbreak of Cucurbit yellow stunting disorder virus in melon, squash and watermelon crops in the Sonoran desert of Arizona and Sonora, Mexico. Plant Dis. 91:773.

5. Brown, J. K., Idris, A. M., Alteri, C., and Stenger, D. C. 2002. Emergence of a new cucurbit-infecting Begomovirus species capable of forming viable reassortants with related viruses in the Squash leaf curl virus Cluster. Phytopathology 92:734-742.

6. Cortez, I., Saaijer, J., Wongjkaew, K. S., Pereira, A. M., Goldbach, R., Peters, D., and Kormelink, R. 2001. Identification and characterization of a novel Tospovirus species using RT-PCR approach. Arch. Virol. 146:265-278.

7. De Avila, A. C., De Haan, P., Kormelink, D., O., Resende, R., Goldbach, R. W., and Peters, D. 1993. Classification of tospoviruses based on phylogeny of nucleoprotein gene sequences. J. Gen. Virol. 74:153-159.

8. Delgadillo, S. F., Garzon, T. J. A., and Vega, P. A. 1989. Cucurbit viruses in Mexico: a survey. Rev. Mex. Fitopatol. 7:136-139.

9. Fauquet, C. M., Mayo, M. A., Maniloff, J., Desselberger, U., and Ball, L. A. 2005. Virus taxonomy. Pages 712-716 in: Eighth Rep. Int. Committee Taxonomy of Viruses. Elsevier Academic Press, London.

10. Felsenstein, J. 1989. PHYLIP—phylogeny inference package (version 3.2). Cladistics 5(2):164-166.

11. Goldbach, R., and Peters, D. 1996. Molecular and biological aspects of tospoviruses. Pages 129-157 in: The Bunyaviridae. R. M. Elliott, ed. Plenum Press, New York \& London.

12. Hassani-Mehraban, A., Saaijer, J., Peters, D., Goldbach, R., and Kormelink, R. 2005. A new tomato-infecting tospovirus from Iran. Phytopathology 95:852-858.

13. Jain, R. K., Pappu, H. R., Pappu, S. S., Krishna
Reddy, M., and Vani, A. 1998. Watermelon bud necrosis tospovirus is a distinct virus species belonging to serogroup IV. Arch. Virol. 143:1637-1644

14. Kato, K., and Hanada, K. 2000. Characterization of the S RNA segment of Melon yellow spot virus. Jpn. J. Phytopathol. 66:252-254.

15. Moyer, J. W. 1999. Tospoviruses (Bunyaviridae). Pages 1803-1807 in: Encyclopedia of Virology. A. Granoff and R. G. Webster, eds. Academic Press, New York.

16. Mumford, R. A., Barker, I., and Wood, K. R. 1996. The biology of the tospoviruses. Ann. Appl. Biol. 128:159-183.

17. Nagata, T., Carvalho, K. R., Noronha, E. F., Sodre, R. D. A., Dutra, LS, Oliveira, P. A., Lovato, F. A., Resende, R. O., De Avila, A. C., and Inouya-Nagata, A. K. 2007. The glycoprotein gene of Chrysanthemum stem necrosis virus and Zucchini lethal chlorosis virus and molecular relationship with other tospoviruses. Virus Genes 35:785-793.

18. Nathanson, N., and Gonzàles-Scarano, F. 1999. Bunyaviridae, general features. Pages 204-212 in: Encyclopedia of Virology. A. Granoff and R. G. Webster, eds. Academic Press, New York.

19. Page, R. D. M. 1996. TreeView: an application to display phylogenetic trees on personal computers. Comput. Appl. Biosci. 12:357-358.

20. Pappu, H. R. 2008. Tomato spotted wilt virus (Bunyaviridae). Pages 133-138 in: Encyclpedia of Virology, Vol V, 3rd ed. B. W. J. Mahy and M. H. V. van Regenmortel, eds. Elsevier Ltd., Oxford.

21. Pappu, S. S., Bhat, A. I., Pappu, H. R., Deom, C. M., and Culbreath, A. K. 2000. Phylogenetic studies of tospoviruses (family Bunyaviridae) based on intergenic region sequences of small and medium genomic RNAs. Arch. Virol. 145:1035-1045.

22. Ramirez-Arredondo, J. A., Armenta-Cardens, I., Delgadillo-Sanchez, F., Rivera-Bustamante, R. F., and Garzon-Tiznado, J. A. 1995. Geminiviruses transmitted by whitefly (Bemisia tabaci) in crops of pepper and squash in Mayo Valley, Sonora, Mexico. Rev. Mex. Fitopatol. 13:100-105.

23. Roggero, P., Ciuffo, M., Vaira, A. M., Accotto, G. P., Masenga, V., and Milne, R. G. 2000. An ophiovirus isolated from lettuce with big-vein symptoms. Arch. Virol. 145:2629-2642.

24. Roggero, P., Ciuffo, M., Vaira, A. M., and Milne, R. G., 1998. Rapid purification of tospovirus nucleocapsids for antibody production and RNA analysis. Pages 25-28 in: Recent Progress in Tospovirus and Thrips Research. D. Peters and R. Goldbach, eds. Wageningen University, Wageningen, The Netherlands.

25. Sanger, F., Bicken, S., and Coulson, A. R. 1977. DNA sequencing with chain terminating inhibitors. Proc. Natl. Acad. Sci. USA 74:5463-5467.

26. Sherwood, J. L., German, T. L., Moyer, J. W., Ullman, D. E., and Whitfield, A. E. 2000. Tomato spotted wilt virus. Pages 1030-1031 in: Encyclopedia of Plant Pathology. O. C. Maloy and T. D. Murray, eds. John Wiley \& Sons, New York.

27. Sin, S.-H., McNulty, B. C., Kennedy, G. G., and Moyer, J. W. 2005. Viral genetic determinants for thrips transmission of Tomato spotted wilt virus. Proc. Natl. Acad. Sci. USA 102:5168-5173.

28. Soellick, T. R., Uhrig, J. F., Bucher, G. L., Kellmann J. W., and Schreier, P. H. 2000. The movement protein NSm of Tomato spotted wilt tospovirus (TSWV): RNA binding, interaction with the TSWV $\mathrm{N}$ protein, and identification of interacting plant proteins. Proc. Natl. Acad. Sci. USA 70:2373-2378.

29. Storms, M. M. H. Kormelink, R., Peters D. Van Lent, J. W. M., and Goldbach, R. W. 1995. The nonstructural protein of Tomato spotted wilt virus induces tubular structures in plant and insect cells. Virology 214:485-493.

30. Strimmer, K., and von Heaselen, A.1996. Quartet puzzling: a quartet maximumlikelihood method for reconstructing tree topologies. Mol. Biol. Evol. 13:964-969.

31. Takeda, A., Sugiyama, K., Nagano, H., Mori, M., Kaido, M., Mise, K., Tsuda, S., and Okumo, T. 2002. Identification of a novel RNA silencing suppressor, NSs protein of Tomato spotted wilt virus. FEBS Lett. 532:75-79.

32. Thompson, J. D., Higgins, D. G., and Gibson, T. J. 1994. Clustal W: improving the sensitivity of progressive multiple sequence alignment through sequence weighting, position-specific gap penalties and weight matrix choice. $\mathrm{Nu}$ cleic Acids Res. 22:4673-4680.

33. Tsompana, M., Abad, J., Purugganan M., and Moyer, J. W. 2005. The molecular population genetics of the Tomato spotted wilt virus (TSWV) genome. Mol. Ecol. 14:53-66.

34. Tsompana, M., and Moyer, J. W. 2008. Tospoviruses. Pages 157-163 in: Encyclpedia of Virology, Vol. V, 3rd ed. B. W. J. Mahy and M. H. V. van Regenmortel, eds. Elsevier Ltd., Oxford.

35. Turina, M., Ciuffo, M., Lenzi, R., Rostagno, L., Mela, E., and Palmano. S. 2006. Characterization of four species belonging to the family Potyviridae isolated from Ranunculus asi aticus. Phytopathology 96:560-566.

36. Turina, M., Desvoyes, B., and Scholthof, K.-B. 2000. A gene cluster encoded by Panicum mosaic virus is associated with virus movement. Virology 266:120-128.

37. Turina, M., Ricker, M. D., Lenzi, R., Masenga, V., and Ciuffo, M. 2007. A severe disease of tomato in the Culiacan Area (Sinaloa, Mexico) is caused by a new picorna-like viral species. Plant Dis. 91:932-941.

38. van Knippernberg, I., Goldbach, R., and Kormelink, R. 2005. Tomato spotted wilt virus $\mathrm{S}$ segment mRNA have overlapping 3 '-end containing a predicted stem loop structure and conserved sequence motif. Virus Res. 110:125131.

39. Whitfield, A. E., Ullman, D. E., and German, T. L. 2005. Tospovirus-thrips interactions. Annu. Rev. Phytopathol. 43:459-89.

40. Yeh, S.-D., Lin, Y.-C., Cheng Y. H., Jih, C.-L., Chen, M.-J., and Chen, C.-C. 1992. Identification of tomato spotted wilt-like virus on watermelon in Taiwan. Plant Dis. 76:835-840.

41. Zucker, M. 2003. Mfold web server for nucleic acid folding and hybridization prediction. $\mathrm{Nu}-$ cleic Acids Res. 31:3406-3415. 